\title{
EFFECT OF APPLICATION TIME OF NK- FERTILIZER AND FOLIAR SPRAYING WITH ASCOBIEN COMPOUND ON PRODUCTION OF HYBRID RICE SEED

\author{
Sorour, S. Gh. R. ${ }^{1}$, M. I. Abo Youssef ${ }^{2}$, A. A. A. Mohamed ${ }^{1}$ and \\ M. A. Tawfik ${ }^{2}$ \\ 1 Agronomy Department, Faculty of Agriculture, Kafrelsheikh University \\ 2 Rice Research \& Training Center, Sakha, Kafrelsheikh, Field Crops \\ Research Institute, Agriculture Research Center
}

\begin{abstract}
Two field experiments were carried out at the Experimental Farm of the Rice Research and Training Center (RRTC), Sakha, Kafrelshiekh, Egypt, during 2012 and 2013 rice seasons; the study to identify the optimum time for Nitrogen, Potassium fertilizer growing application and foliar of ascobien compound application on growth and yield characters to increase the productivity of hybrid rice seed. The study included that two parental lines the first was IR69625 A as female line, with abortive sterility and the second was Giza178 cultivar as restorer line to produce $F_{1}$ hybrid seed. The experimental design was A split - split plot design with three replications. The obtained results could be summarized as follows:

Increasing the number of nitrogen fertilizer application time, especially when it applied at booting stage, resulted in a significant increase in heading date, plant height, flag leaf angel, flag leaf area, number of tillers hill ${ }^{-1}$, number of panicle hill ${ }^{-1}$, panicle length, panicle weight, number of filled grains panicle ${ }^{-1}$, seed set\%, 1000grain weight, grain yield and harvest index\% in both seasons. The highest seed yield was obtained when nitrogen fertilizer was adding in four equal doses in both seasons.

The highest seed yield was obtained when potassium fertilizer was applied in two equal doses as basal soil and especially when it added at Panicle initiation stage (SI). Application of K- fertilizer at the two equal doses (SI) resulted in a significant increase in number of panicle hill ${ }^{-1}$, panicle exertion, panicle length, panicle weight, number of filled grains panicle ${ }^{-1}$, seed set $\%, 1000$ - grain weight, grain yield, harvest index \% in both seasons.

The foliar application of ascobien compound at 25 and 45 days after transplanting recorded that the highest and significant values of heading date, plant height, flag leaf angel, flag leaf area, number of tillers hill ${ }^{-1}$, number of panicle hill ${ }^{-1}$, panicle exertion, panicle length, panicle weight, number of filled grains panicle ${ }^{-1}$, seed set $\%, 1000$ - grain weight, grain yield and harvest index \% compared with other applications in both seasons.

The all interaction between and among the three factors under study showed a significant effect on a lot of characters especially in the grain yield in the two seasons of study.

From this study, it can be concluded that application of nitrogen on four equal doses (STIB), potassium in two equal doses (SI) and foliar application of ascobien at 25 and 45 days after transplanting could be recommended for optimum productivity of hybrid rice seed (SK $2034 \mathrm{H})$.
\end{abstract}

\section{INTRODUCTION}

Rice (Oryza sativa,L.) is considered as one of the most important cereal crops not only in Egypt, but also in the world. The yearly cultivated 
area by rice in Egypt is almost more than one fifth of the total area. The total cultivated area of rice in Egypt was about 0.6 million ha, which produced 7.24 million tons of paddy rice with an average of 9.56 t/ha. RRTC (2012). In spite of the fact that Egypt has a high average of rice grain yield, but, to increase the productivity per unit area and water is a matter of importance and challenge.

Hybrid rice has more panicle and more spikelets panicle- 1 but, filled spikelets percentage was less probably due to higher nutrient during reproductive growth stage. Hybrid rice requires different strategies for nitrogen management to maximize expression of their yield. Thereby, top dressing a small part of nitrogen at the late growth stage is expected to realize the full grain yield potential of hybrid rice. Nitrogen application at flowering stage was found to be effective in increasing filled spikelets panicle1 and raised panicle weight leading to higher grain yield of hybrid rice. Virmani (1996) in IRRI

Nitrogen fertilization is very important for plant growth and its survival, it has to be applied at the optimum rate meets the plants needs, not only the amount of nitrogen added but also, the time and methods of its application. Nitrogen fertilization applied to meet the require plants during the nearly growth accumulates in the vegetative parts is utilized for grain formation. A large portion of the nitrogen absorbed of differentiation. The leaves and stems contain a large portion of the nitrogen taken up by the plant (Ebaid and Ghanem, 2001).

Potassium is linked with all phenomena of plant photosynthesis, respiration, metabolism of fats, carbohydrates and nitrogenous compounds, enzyme activation, cell elongation and water efficiency, so it is considered the key element in hybrid rice nutrition for improving root growth and plant vigor, helping to prevent lodging and enhancing rice resistance to pests and diseases (Krishnakumar et al. 2005).

Ascorbic acid has effects on many physiological processes including the regulation of growth and metabolism of plants (Foyer, 1993). Ascorbic acid is small, water-soluble molecule, which acts as a primary substrate in the cycling pathway for detoxification and neutralization of superoxide radicals and singlet oxygen (Noctor and Foyer, 1998 and Smirnoff, 2005). These free radicals may cause oxidative stress resulting in cellular damage by oxidation of lipids, proteins and nucleic acids so, ascorbic acid protect metabolic processes, Noctor and Foyer, (1998). Also, latter has important role in vital process in plant growth such as cell division and cell wall expansion (Pignocchi and Foyer, 2003). Moreover, ascorbic acid plays important role in ascorbate-glutathione pathway and scavenges reactive oxygen species in chloroplast (Foyer and Harbinson, 1994). Ascorbic foliar application increased the yield of some crops as found by Ghourab and Wahdan (2000), El-Shazly and El-Masri (2003) on cotton, Abd El-Hameed et al. (2004) on wheat, Taha, Hanan (2008) and Gharib, et al (2011) on rice.

The main of this research was to identify the optimum time for Nitrogen, Potassium fertilizer growing application and foliar of ascobien compound application on growth and yield characters to increase the productivity of hybrid rice seed 


\section{MATERIALS AND METHODS}

Two field experiments were carried out at the Experimental Farm of the Rice Research and Training Center (RRTC), Sakha, Kafr El-Sheikh, Egypt, in 2012 and 2013 seasons, to determine the optimum application time of Nitrogen, Potassium fertilizer and foliar spraying with ascobien compound and its effect on growth characters, yield and its components of hybrid rice seed production (SK $2034 \mathrm{H}$ ). The previous crop was alfalfa in the both seasons.

Representative soil samples were taken from each site at the depth of $0-30 \mathrm{~cm}$ from the soil surface. Samples were air-dried then ground to pass through a two $\mathrm{mm}$ sieve and well mixed. The procedure of soil analysis followed the methods of Black et al. (1965). Results of chemical analysis in both seasons are shown in Table 1.

Table 1: Some chemical properties of the soil in the experimental sites in 2012 and 2013 seasons

\begin{tabular}{|c|c|c|}
\hline Character & 2012 & 2013 \\
\hline Texture & Clay & Clay \\
\hline $\mathrm{pH}$ & 7.7 & 8.1 \\
\hline EC $\quad(\mathrm{ds} / \mathrm{m})$ & 1.83 & 2.3 \\
\hline OM $(\%)$ & 1.4 & 1.5 \\
\hline $\mathrm{Ca}++\quad$ (meq. $\left.^{-1}\right)$ & 4.80 & 4.43 \\
\hline $\mathrm{Mg}++\quad$ (meq. $\left.^{-1}\right)$ & 5.01 & 5.12 \\
\hline $\mathrm{K}+\quad$ (meq. $\left.\mathrm{I}^{-1}\right)$ & 4.70 & 4.68 \\
\hline Available $\mathrm{K} \quad\left(\mathrm{mg} \mathrm{kg}^{-1}\right)$ & 350 & 363 \\
\hline Available P $\quad\left(\mathrm{mg} \mathrm{kg}^{-1}\right)$ & 13 & 16.5 \\
\hline Total nitrogen $\left(\mathrm{mg} \mathrm{kg}^{-1}\right)$ & 450 & 560 \\
\hline Available $\mathrm{Zn} \quad\left(\mathrm{mg} \mathrm{kg}^{-1}\right)$ & 0.71 & 0.93 \\
\hline Available $\mathrm{Fe} \quad\left(\mathrm{mg} \mathrm{kg}^{-1}\right)$ & 4.98 & 6.12 \\
\hline Available $\mathrm{Mn}\left(\mathrm{mg} \mathrm{kg}^{-1}\right)$ & 2.29 & 3.60 \\
\hline
\end{tabular}

The materials under study included two parental lines, IR69625A as female line with abortive sterility and Giza178 cultivar as restorer line to produce $\mathrm{F}_{1}$ hybrid seed for promising hybrid SK.2034 $\mathrm{H}$.

The experimental design was split-split plot design with three replications. The main plots were assigned to nitrogen application time, the sub-plots to potassium application time and the sub -sub plots to foliar applications time of ascbien compound as follows:

A-Nitrogen application time (main plots).

Nitrogen fertilizer in the form of urea $46 \%$ at the rate of $165 \mathrm{~kg} \mathrm{~N} / \mathrm{ha}$ was distributed at different growth stage of rice as follows:

\begin{tabular}{|l|c|c|c|c|c|}
\hline \multirow{2}{*}{$\begin{array}{c}\text { Time of } \\
\text { application }\end{array}$} & Basal soil & Mid-tillering & $\begin{array}{c}\text { Panicle } \\
\text { initiation }\end{array}$ & $\begin{array}{c}\text { Booting } \\
\text { stage }\end{array}$ & Total \\
\cline { 2 - 6 } & 55 & 55 & 55 & - & 165 \\
\hline STI & 41.25 & 41.25 & 41.25 & 41.25 & 165 \\
\hline STIB & 82.5 & 82.5 & - & - & 165 \\
\hline ST & 110 & 55 & - & - & 165 \\
\hline
\end{tabular}

$\mathrm{S}=$ Basal soil, $\mathrm{T}=$ Mid-tillering, $\mathrm{I}=$ Panicle initiation and $\mathrm{B}=$ Booting stage 


\section{B-Potassium application time (sub-plots).}

Potassium fertilizer in the form of potassium sulphate $\left(48 \% \mathrm{~K}_{2} \mathrm{O}\right)$ at the rate of $60 \mathrm{~kg} \mathrm{~K} \mathrm{~K}_{2} \mathrm{O} / \mathrm{ha}$ was distributed at different growth stage of rice stages as follows:

\begin{tabular}{|l|c|c|c|}
\hline \multirow{2}{*}{$\begin{array}{c}\text { Time of } \\
\text { applications }\end{array}$} & \multicolumn{3}{|c|}{ Kg K $\mathbf{2}$ / ha } \\
\cline { 2 - 4 } & Basal & Panicle initiation & Total \\
\hline Control & - & - & - \\
\hline S & 60 & - & 60 \\
\hline SI & 30 & 30 & 60 \\
\hline
\end{tabular}

S= Basal soil and I= Panicle initiation

\section{C- Foliar application of ascobien compound (sub-sub plots).}

ascobien compound applications at the rate of $2.5 \mathrm{~kg} / \mathrm{ha}(13 \%$ citric acid, $25 \%$ ascorbic acid plus $62 \%$ organic materials), were add with the concentration of $1 \mathrm{~g} /$ /itre. (1- Control, 2- Once at 25 days after transplanting 3Twice at 25 and 45 days after transplanting).

Other cultural practices were done according the recommendation of growing hybrid rice seed productivity and disseribed by Zaman et al (2002). The data were recorded according to Standard Evaluation System (SES) of IRRI (1998), for all the studied characters i.e. heading date (day), plant height $(\mathrm{cm})$, flag leaf angel $\left({ }^{0}\right)$, flag leaf area $\left(\mathrm{cm}^{2}\right)$ number of tillers/hill, number of fertile panicles/hill, panicle exertion (\%), panicle length $(\mathrm{cm})$, panicle weight $(\mathrm{g})$, number of filled grains/panicle, seed set (\%), 1000 grain weight(g), grain yield (t/ha) and harvest index (\%).

All the data collected were subjected to analysis of variance according to Gomez and Gomez (1984). Treatment means were compared by Duncan's multiple range test Duncan, (1955). All statistical analysis was performed using analysis of variance technique by means of "MSTAT" computer software package.

\section{RESULTS AND DISCUSSION}

\section{1-Growth characters:-}

The mean performance of heading date, plant height, flag leaf angel, flag leaf area and number of tillers per hill ${ }^{-1}$ of IR69625A as affected by nitrogen, potassium fertilizer and foliar application of ascobien compound in 2012 and 2013 are presented in Table 2 \& 3.

\section{Effect of increasing nitrogen applications time:}

Increase number of nitrogen splitting resulted in gradually increase in heading date, plant height, Flag leaf angel, flag leaf area and number of tillers hill $^{-1}$ in the two seasons.

The heights values of the mentioned traits were obtained from adding nitrogen fertilizer in four equal doses, one at each of basal soil, mid-tillering, panicle initiation and booting stage (STIB). Data indicated that nitrogen application at booting stage increased all these traits in the two seasons.

A significant increase in heading date, plant height, flag leaf angel, flag leaf area and number of tillers hill ${ }^{-1}$ were accompanied with increasing number of nitrogen splits. There was no significant difference in plant height between splitting nitrogen in four or three equal doses (STIB \& STI) in the two 
seasons. The continuous nitrogen supply, especially with late application, such effect of nitrogen could be attributed mainly to its role in the stimulation of various physiological processes including increase vegetative period, cell division and cell elongation of internodes resulting in more tillers formation, leaf numbers, delay leaf senescence and photosynthetic rate (leaf area), which led to delay the heading.

Table 2: Heading date (days) and plant height (cm) of IR 69625A as affected by nitrogen, potassium and ascobien compound time applications and their interactions in 2012 and 2013season

\begin{tabular}{|c|c|c|c|c|}
\hline \multirow{2}{*}{$\begin{array}{c}\text { Factor } \\
\text { (time of application) }\end{array}$} & \multicolumn{2}{|c|}{ Heading date (days) } & \multicolumn{2}{|c|}{ Plant heiaht (cm) } \\
\hline & 2012 & 2013 & 2012 & 2013 \\
\hline \multicolumn{5}{|l|}{$\begin{array}{l}\text { Nitrogen (165 kg N/ha) } \\
(\mathrm{N}) \text { : }\end{array}$} \\
\hline STI & $98.30 \mathrm{~b}$ & $99.61 \mathrm{~b}$ & $101.90 \mathrm{a}$ & $102.99 \mathrm{a}$ \\
\hline STIB & $101.53 \mathrm{a}$ & $102.43 \mathrm{a}$ & $102.03 \mathrm{a}$ & $103.28 a$ \\
\hline ST & $94.12 \mathrm{~d}$ & $96.08 \mathrm{~d}$ & $94.31 \mathrm{c}$ & $95.49 \mathrm{c}$ \\
\hline ST 2:1 & $96.71 \mathrm{c}$ & $98.10 \mathrm{c}$ & $97.98 \mathrm{~b}$ & $99.22 \mathrm{~b}$ \\
\hline F - test & $\star *$ & $\star *$ & $\star *$ & $\star *$ \\
\hline \multicolumn{5}{|l|}{$\begin{array}{l}\text { Potassium }\left(60 \mathrm{~kg} \mathrm{k}_{2} \mathrm{O} / \mathrm{ha}\right) \\
(\mathrm{K}):\end{array}$} \\
\hline Control & $99.74 \mathrm{a}$ & $101.07 \mathrm{a}$ & 98.63 & 99.89 \\
\hline S & $98.00 \mathrm{~b}$ & $99.40 \mathrm{~b}$ & 99.06 & 100.27 \\
\hline SI & $95.26 \mathrm{c}$ & $96.69 \mathrm{c}$ & 99.48 & 100.58 \\
\hline F - test & ** & ** & NS & NS \\
\hline \multicolumn{5}{|l|}{ ascobien $(1 \mathrm{gm} / \mathrm{l})(\mathrm{A})$ : } \\
\hline Control & $94.80 \mathrm{c}$ & $96.49 \mathrm{c}$ & $94.57 \mathrm{c}$ & $95.59 \mathrm{c}$ \\
\hline Once & $97.61 \mathrm{~b}$ & $99.10 \mathrm{~b}$ & $99.52 \mathrm{~b}$ & $100.80 \mathrm{~b}$ \\
\hline Twice & $100.58 \mathrm{a}$ & $101.57 \mathrm{a}$ & $103.07 \mathrm{a}$ & $104.35 \mathrm{a}$ \\
\hline F - test & ** & $* \star$ & $* *$ & ** \\
\hline \multicolumn{5}{|l|}{ Interaction: } \\
\hline NXK & NS & NS & NS & NS \\
\hline NXA & $\star *$ & $\star *$ & $\star *$ & $\star *$ \\
\hline KXA & NS & NS & NS & NS \\
\hline NXKXA & NS & NS & NS & NS \\
\hline
\end{tabular}

$\left.{ }^{*}\right)$ Significant at $5 \%$ level, $\left(^{* *}\right)$ highly Significant at $1 \%$ level, and (NS) Not Significan Letter(s) refer to Duncan's multiple range Test

$$
\begin{array}{ll}
\text { S.......... basal soil, } & \text { T....... mid-tillering, } \\
\text { l...... panicle initiation, } & \text { B.......booting stage }
\end{array}
$$

Effect potassium applications Time:

In Table (2) show that no significant effect for the potassium application time on plant height, flag leaf angel, flag leaf area and number of tillers hill ${ }^{-1}$, but there was significant differences in heading date by potassium applications in the two seasons.

Rice plants received potassium fertilizer was earlier in heading than those without potassium fertilizer in both seasons. Days from sowing to heading were losses at splitting potassium in two equal doses (SI) than one dose $(S)$ in the two seasons. This trend was holding true in both seasons of investigation. These findings could mainly be attributed to the positive effect 
of continuous potassium supply until late season, where it pays rice plants to heading early (Mikhael 2010). The results were agreement with, Manjappa et al. (2008) and Manzoor et al. (2008).

Table 3: Flag leaf angel $\left({ }^{\circ}\right)$, flag leaf area $\left(\mathrm{cm}^{2}\right)$ and number of tillers/hill (tiller) of IR 69225A as affected by Nitrogen, potassium and ascobien compound time applications and their interactions in 2012 and 2013 season.

\begin{tabular}{|c|c|c|c|c|c|c|}
\hline \multirow{2}{*}{\begin{tabular}{|c|} 
Factor \\
(time of \\
application)
\end{tabular}} & \multicolumn{2}{|c|}{ Flag leaf angel $\left({ }^{0}\right)$} & \multicolumn{2}{|c|}{ Flag leaf area $\left(\mathrm{cm}^{2}\right)$} & \multicolumn{2}{|c|}{ Tillers (No/hill) } \\
\hline & 2012 & 2013 & 2012 & 2013 & 2012 & 2013 \\
\hline $\begin{array}{l}\text { Nitrogen } \\
(165 \mathrm{~kg} \\
\mathrm{N} / \mathrm{ha})(\mathrm{N}):\end{array}$ & & & & & & \\
\hline STI & $33.34 \mathrm{~b}$ & $34.60 \mathrm{~b}$ & $37.57 \mathrm{~b}$ & $38.76 \mathrm{~b}$ & $22.50 \mathrm{~b}$ & $23.33 \mathrm{~b}$ \\
\hline STIB & $35.39 a$ & $36.68 \mathrm{a}$ & $41.43 \mathrm{a}$ & $41.77 \mathrm{a}$ & $27.42 \mathrm{a}$ & $28.24 \mathrm{a}$ \\
\hline ST & $30.41 \mathrm{c}$ & $32.43 \mathrm{c}$ & $34.93 \mathrm{c}$ & $36.38 \mathrm{c}$ & $17.58 \mathrm{~d}$ & $18.80 \mathrm{~d}$ \\
\hline ST 2:1 & $30.80 \mathrm{c}$ & $32.73 \mathrm{c}$ & $35.34 \mathrm{c}$ & $36.71 \mathrm{c}$ & $19.56 \mathrm{c}$ & $20.62 \mathrm{c}$ \\
\hline $\mathrm{F}-$ test & ** & ** & ** & ** & ** & ** \\
\hline $\begin{array}{l}\text { Potassium } \\
(60 \mathrm{~kg} \\
\left.\mathrm{k}_{2} \mathrm{O} / \mathrm{ha}\right)(\mathrm{K}):\end{array}$ & & & & & & \\
\hline Control & 32.05 & 33.66 & 37.11 & 38.03 & 21.17 & 22.10 \\
\hline$S$ & 32.33 & 34.06 & 37.19 & 38.41 & 21.67 & 22.79 \\
\hline SI & 33.08 & 34.62 & 37.66 & 38.77 & 22.45 & 23.35 \\
\hline $\mathrm{F}-$ test & NS & NS & NS & NS & NS & NS \\
\hline $\begin{array}{l}\text { ascobien (1 } \\
\mathrm{gm} / \mathrm{l})(\mathrm{A}):\end{array}$ & & & & & & \\
\hline Control & $29.72 \mathrm{c}$ & $31.33 \mathrm{c}$ & $33.77 \mathrm{c}$ & $35.31 \mathrm{c}$ & $15.59 \mathrm{c}$ & $16.96 \mathrm{C}$ \\
\hline Once & $32.62 \mathrm{~b}$ & $34.49 \mathrm{~b}$ & $37.37 \mathrm{~b}$ & $38.37 \mathrm{~b}$ & $22.78 \mathrm{~b}$ & $23.72 \mathrm{~b}$ \\
\hline Twice & $35.12 \mathrm{c}$ & $36.51 \mathrm{a}$ & $40.81 \mathrm{a}$ & $41.54 \mathrm{a}$ & $26.91 a$ & $27.56 \mathrm{a}$ \\
\hline $\mathrm{F}-$ test & ** & ** & $\star *$ & ** & ** & $\star \star *$ \\
\hline Interaction: & & & & & & \\
\hline NXK & NS & NS & NS & NS & NS & NS \\
\hline NXA & NS & NS & ** & ** & ** & ** \\
\hline KXA & NS & NS & NS & NS & NS & NS \\
\hline NXKXA & NS & NS & NS & NS & NS & NS \\
\hline
\end{tabular}

$\left({ }^{*}\right)$ Significant at $5 \%$ level, $\left({ }^{* *}\right)$ highly Significant at $1 \%$ level, and (NS) Not Significant Letter(s) refer to Duncan's multiple range Test
S...... basal soil,
T...... mid-tillering,

I....... panicle initiation,

B........booting stage

The effects of nitrogen splitting on heading date, plant height, flag leaf angel, flag leaf area and number of tillers were reported by Surekha et al., (1999), Dheebakaran and Ramasaamy (2000), Gorgey et al. (2006) and Mikhael,. (2007).

\section{Effect of ascobien compound applications time:}

Foliar application of ascobien compound had a significant effect on all pervious characters in both seasons. Plants sprayed with ascobien compound significantly exceeded those without spraying (control) in the two seasons.

Spraying plants with ascobien compound twice increased all this traits in the two seasons. The effect of foliar application with ascobien compound on these growth traits may be due to combined action of both ascorbic and citric acid on cell elongation division and cell enlargement, 
which reflected positively on days to heading, plant height and number of tillers Taha, (2008). These results are in agreement with those obtained by Gharib et al., (2011), who found that foliar spraying with ascobien at the beginning of rice tillering stage resulted in a significant increase in number of tillers $/ \mathrm{m}^{2}$ of rice compared with the control treatment. Also the foliar spraying with ascobien at different growth stages revealed no significant difference in plant height at harvest in both seasons. In this respect Abd El-Hameed et al., (2004), on wheat, reported that citric and ascorbic acids at 1500 ppm increased plant height.

Table 4: Number of panicles/hill (panicl), Panicle exertion (\%) and Panicle length $(\mathrm{cm})$ of IR 69625A as affected by Nitrogen, potassium, ascobin compound time applications and their interactions in 2012 and 2013 seasons

\begin{tabular}{|c|c|c|c|c|c|c|}
\hline \multirow{2}{*}{\begin{tabular}{|c|} 
Factor \\
(time of \\
application)
\end{tabular}} & \multicolumn{2}{|c|}{ Panicles (No/hill) } & \multicolumn{2}{|c|}{ Panicle exertion (\%) } & \multicolumn{2}{|c|}{ Panicle length $(\mathrm{cm})$} \\
\hline & 2012 & 2013 & 2012 & 2013 & 2012 & 2013 \\
\hline $\begin{array}{l}\text { Nitrogen } \\
(165 \mathrm{~kg} \\
\mathrm{N} / \mathrm{ha})(\mathrm{N}):\end{array}$ & & & & & & \\
\hline STI & $17.04 \mathrm{~b}$ & $18.48 \mathrm{~b}$ & $72.94 \mathrm{~b}$ & $73.74 \mathrm{~b}$ & $22.04 \mathrm{~b}$ & $22.24 \mathrm{~b}$ \\
\hline STIB & $20.14 \mathrm{a}$ & $21.36 \mathrm{a}$ & $70.87 \mathrm{c}$ & $71.58 \mathrm{c}$ & $23.52 \mathrm{a}$ & $23.84 \mathrm{a}$ \\
\hline ST & $13.37 \mathrm{c}$ & $14.79 \mathrm{c}$ & $76.16 \mathrm{a}$ & $76.06 \mathrm{a}$ & $20.54 \mathrm{c}$ & $20.84 \mathrm{c}$ \\
\hline ST 2:1 & $14.00 \mathrm{c}$ & $15.24 \mathrm{c}$ & $76.66 \mathrm{a}$ & $77.10 \mathrm{a}$ & $20.90 \mathrm{c}$ & $21.01 \mathrm{c}$ \\
\hline $\mathrm{F}$ - test & $\star \star$ & $\star \star$ & $\star \star$ & $\star \star$ & $\star \star$ & $\star \star$ \\
\hline $\begin{array}{l}\text { Potassium } \\
(60 \mathrm{~kg} \\
\left.\mathrm{K}_{2} \mathrm{O} / \mathrm{ha}\right)(\mathrm{K}):\end{array}$ & & & & & & \\
\hline Control & $11.37 \mathrm{c}$ & $12.47 \mathrm{c}$ & $67.89 \mathrm{c}$ & $68.81 \mathrm{c}$ & $20.15 \mathrm{c}$ & $20.46 \mathrm{c}$ \\
\hline S & $16.84 \mathrm{~b}$ & $18.16 \mathrm{~b}$ & $74.35 \mathrm{~b}$ & $74.59 \mathrm{~b}$ & $21.98 \mathrm{~b}$ & $22.30 \mathrm{~b}$ \\
\hline SI & $20.21 \mathrm{a}$ & $21.77 \mathrm{a}$ & $80.24 \mathrm{a}$ & $80.46 \mathrm{a}$ & $23.12 \mathrm{a}$ & $23.18 \mathrm{a}$ \\
\hline F - test & $\star \star$ & $\star \star$ & $\star *$ & $\star \star$ & $\star \star$ & $\star \star$ \\
\hline $\begin{array}{l}\text { ascobien (1 } \\
\mathrm{gm} / \mathrm{l})(\mathrm{A}) \text { : }\end{array}$ & & & & & & \\
\hline Control & $11.79 \mathrm{c}$ & $13.08 \mathrm{c}$ & $69.24 \mathrm{c}$ & $69.84 \mathrm{c}$ & $19.46 \mathrm{c}$ & $19.82 \mathrm{c}$ \\
\hline Once & $16.69 \mathrm{~b}$ & $17.54 \mathrm{~b}$ & $74.64 \mathrm{~b}$ & $75.05 \mathrm{~b}$ & $22.05 \mathrm{~b}$ & $22.17 \mathrm{~b}$ \\
\hline Twice & $19.93 \mathrm{a}$ & $21.78 \mathrm{a}$ & $78.60 \mathrm{a}$ & $78.97 \mathrm{a}$ & $23.73 \mathrm{a}$ & $23.96 \mathrm{a}$ \\
\hline F - test & $\star \star$ & $\star \star$ & ** & $\star \star$ & $\star \star$ & $\star \star$ \\
\hline Interaction: & & & & & & \\
\hline NXK & ** & ** & ${ }^{\star}$ & $\star *$ & ${ }^{* *}$ & ** \\
\hline NXA & ${ }^{\star *}$ & ${ }^{* *}$ & $\star \star$ & $\star \star$ & NS & NS \\
\hline KXA & NS & NS & ** & ** & NS & NS \\
\hline NXKXA & ${ }^{\star *}$ & ${ }^{\star *}$ & ** & ** & NS & NS \\
\hline
\end{tabular}

$\left({ }^{*}\right)$ Significant at $5 \%$ level, $\left({ }^{* *}\right)$ highly Significant at $1 \%$ level, and (NS) Not Significant Letter(s) refer to Duncan's multiple range Test

\section{Effect of interaction:}
S...... basal soil,
T...... mid-tillering,
I....... panicle initiation,
B........booting stage

The interaction between nitrogen fertilizer and foliar spraying with ascobien compound time had a significant effect on heading date, plant height, flag leaf area and number of tillers/hill in both seasons (Tables 2\&3). None of the other interaction significantly affected all these traits in both seasons. 


\section{2- Yield and its components:-}

The means of panicle numbers, panicle exertion, panicle length, panicle weight, number of filled grains and seed set \%, of IR 69625A as affected by nitrogen, potassium splitting and foliar application with ascobien compound time of in 2012 and 2013 are presented in Tables (4 \& 5).

\section{Effect of nitrogen applications time:}

All yield attributes were significantly affected by nitrogen applications time in both seasons. Number of panicle hill ${ }^{-1}$, panicle exertion, panicle length, panicle weight, number of filled grains panicle ${ }^{-1}$ and seed set were increased by increasing splitting the nitrogen fertilizer from 2 to 4 doses in the two seasons.

Table 5: Number of fertile grain/panicle (panicle), Seed set (\%) and Panicle weight $(\mathrm{g})$ of IR $69225 \mathrm{~A}$ as affected by Nitrogen, potassium, ascobin compound time applications and their interactions in 2012 and 2013

\begin{tabular}{|c|c|c|c|c|c|c|}
\hline \multirow{2}{*}{\begin{tabular}{|c|}
$\begin{array}{c}\text { Factor } \\
\text { (time of } \\
\text { application) }\end{array}$ \\
\end{tabular}} & \multicolumn{2}{|c|}{ Panicle weight (g) } & \multicolumn{2}{|c|}{$\begin{array}{c}\text { Fertile grains } \\
\text { (No/panicle) }\end{array}$} & \multicolumn{2}{|c|}{ Seed set (\%) } \\
\hline & 2012 & 2013 & 2012 & 2013 & 2012 & 2013 \\
\hline \multicolumn{7}{|l|}{$\begin{array}{l}\text { Nitrogen } \\
(165 \mathrm{~kg} \\
\mathrm{N} / \mathrm{ha})(\mathrm{N}):\end{array}$} \\
\hline STI & $1.97 \mathrm{~b}$ & $2.22 \mathrm{~b}$ & $51.58 \mathrm{~b}$ & $53.82 b$ & $35.16 \mathrm{~b}$ & $34.07 b$ \\
\hline STIB & $2.26 \mathrm{a}$ & $2.47 \mathrm{a}$ & $62.45 \mathrm{a}$ & $63.71 \mathrm{a}$ & $38.69 \mathrm{a}$ & $37.68 \mathrm{a}$ \\
\hline ST & $1.55 \mathrm{c}$ & $1.70 \mathrm{c}$ & $43.48 \mathrm{c}$ & $47.14 \mathrm{c}$ & $28.98 \mathrm{c}$ & $27.73 \mathrm{c}$ \\
\hline ST 2:1 & $1.61 \mathrm{c}$ & $1.77 \mathrm{c}$ & $43.86 \mathrm{c}$ & $47.38 \mathrm{c}$ & $29.538 \mathrm{c}$ & $28.29 \mathrm{c}$ \\
\hline $\mathrm{F}$ - test & $\star *$ & $\star \star *$ & $\star \star$ & $\star \star$ & $\star \star *$ & $\star \star$ \\
\hline \multicolumn{7}{|l|}{$\begin{array}{l}\text { Potassium } \\
(60 \mathrm{~kg} \\
\left.\mathrm{k}_{2} \mathrm{O} / \mathrm{ha}\right)(\mathrm{K}):\end{array}$} \\
\hline Control & $1.53 \mathrm{c}$ & $1.63 \mathrm{c}$ & $38.90 \mathrm{c}$ & $43.17 c$ & $25.30 \mathrm{c}$ & $24.07 \mathrm{c}$ \\
\hline$S$ & $1.84 \mathrm{~b}$ & $2.02 \mathrm{~b}$ & $51.33 \mathrm{~b}$ & $52.35 \mathrm{~b}$ & $34.24 \mathrm{~b}$ & $32.45 \mathrm{~b}$ \\
\hline SI & $2.18 \mathrm{a}$ & $2.47 \mathrm{a}$ & $60.80 \mathrm{a}$ & $63.51 \mathrm{a}$ & $39.73 \mathrm{a}$ & $39.31 \mathrm{a}$ \\
\hline F - test & $\star \star$ & $\star \star$ & $\star \star$ & $\star \star$ & $\star \star$ & $\star \star$ \\
\hline \multicolumn{7}{|l|}{$\begin{array}{l}\text { ascobien }(1 \\
\mathrm{gm} / \mathrm{I})(\mathrm{A}) \text { : }\end{array}$} \\
\hline Control & $1.49 \mathrm{c}$ & $1.57 \mathrm{c}$ & $41.64 \mathrm{C}$ & $44.08 \mathrm{c}$ & $25.43 \mathrm{c}$ & $24.34 \mathrm{c}$ \\
\hline Once & $1.81 \mathrm{~b}$ & $2.19 \mathrm{~b}$ & $49.19 \mathrm{~b}$ & $51.60 \mathrm{~b}$ & $34.82 \mathrm{~b}$ & $32.57 \mathrm{~b}$ \\
\hline Twice & $2.25 \mathrm{a}$ & $2.36 \mathrm{a}$ & $60.19 \mathrm{a}$ & $63.35 \mathrm{a}$ & $39.03 \mathrm{a}$ & $38.92 \mathrm{a}$ \\
\hline F - test & $\star \star$ & $\star \star *$ & $\star \star$ & $\star \star$ & $\star \star$ & $\star \star$ \\
\hline \multicolumn{7}{|l|}{ Interaction: } \\
\hline NXK & ** & ** & ** & ** & ** & ** \\
\hline NXA & ** & ** & ** & ** & $* *$ & ** \\
\hline KXA & ** & ** & ** & ** & ** & ** \\
\hline NXKXA & ** & ** & ** & ** & $\star *$ & $* *$ \\
\hline
\end{tabular}

$\left({ }^{\star}\right)$ Significant at $5 \%$ level, $\left(^{* \star}\right)$ highly Significant at $1 \%$ level, and (NS) Not Significant Letter(s) refer to Duncan's multiple range Test
S...... basal soil,
T...... mid-tillering,
I........ panicle initiation, B.......booting stage

The highest values of at mentioned traits were obtained from adding nitrogen fertilizer in four equal doses, one at each of basal soil, mid-tillering, 
panicle initiation and booting stage (STIB). Data indicated that nitrogen application at booting stage increased most of these traits in the two seasons.

On the other hand, the two lower nitrogen treatments (ST 2:1 and ST) resulted in a significant increase in panicle exertion compared with the two higher doses. Such result indicates that with increase time's doses nitrogen, will enhancement the tillering ability then develop effective panicles/hill. The reduction in panicle exertion may be due to excessive content of nitrogen in plant, may really be due to as a result of the payment of the plant to Nau vegetative and flowering delay(IRRI 1998);. Similar findings were reported by Peng et al., (1996); Stalin et al., (1999); Surekha et al., (1999) and Badasubramanian, R. (2002).

\section{Effect of potassium applications time:}

The Data showed that applying the potassium fertilizer resulted in gradually increase in number of panicle hill ${ }^{-1}$, panicle exertion, panicle length, panicle weight, number of filled grains panicle ${ }^{-1}$ and seed set\% in both seasons.

The highest values of the mentioned traits were obtained with adding potassium fertilizer in two equal doses as half dose as basal soil + half dose at panicle initiation stage (SI) compared with other treatments. Results reveled that potassium application at panicle initiation stage increased all these traits in the two seasons. These results might be due to adding $50 \%$ of potassium fertilizer at basal soil encouraged faster and earlier growth and improved the photosynthesis rate, which consequently increased stored carbohydrates at pre-heading which relatively trans located to the panicles, consequently increased filling of spikelet's. Moreover, add potassium at panicle initiation improved flag leaf area and leaf chlorophyll content contributed to improve current photosynthesis and carbohydrate formation at post-heading. This might be the continuous supply of $\mathrm{K}$ to the rice plant during crop growth stages which its more effective will increase the total number of panicles, panicle exertion and number of filled grains panicle ${ }^{-1}$ (Awan et al. 2007). These findings are in close conformity with those of Meena et al. (2003), Zaratin et al. (2004), Tahir et al. (2007) and Manzoor et al. (2008).

\section{Effect of ascobien compound applications time:}

Foliar application of ascobien compound exerted a significant effect on in number of panicle hill ${ }^{-1}$, panicle exertion\%, panicle length, panicle weight, number of filled grains panicle ${ }^{-1}$ and seed set\%, in the two seasons.

Spraying ascobien compound as a foliar application gave the highest values of all previous traits in the two times at 25 and 45 day after transplanting (twice).

Data indicated that plants sprayed twice with ascobien compound significantly exceeded those without spraying (control) or the other applications in the two seasons. The increase in yield attributes with foliar application of ascobien was possibly due to enhancement the growth of rice plants (Taha, 2008). These results are confirmed with the findings of Gharib et al., (2011). 


\section{Effect of interaction:}

Data in Tables (4\&5) showed, all possible interactions had a highly significant effect on most of yield characters, during both 1st and 2nd seasons. The interaction between nitrogen with potassium splitting and nitrogen splits with ascobien compound, which had not significant on panicle length, also not significant in number of panicles/hill and panicle length by potassium spliting with ascobien compound applications time in both seasons.

\section{3-1000-grain weight, grain yield and harvest index:-}

The mean performance of 1000-grain weight, grain yield/ ha and harvest index of IR 69625A as affected by nitrogen, potassium fertilizer splitting and foliar application of ascobien compound in 2012 and 2013 are presented in Ttable 6.

\section{Effect of nitrogen applications time:}

Increasing number of nitrogen splitting resulted in gradually increase in1000-grain weight, grain yield/ ha and harvest index were obtained among nitrogen treatments in both seasons.

The highest values of the previous traits were obtained from adding nitrogen fertilizer in four equal doses, one at each of basal soil, mid-tillering, panicle initiation and booting stage (STIB). Data indicated that nitrogen application at booting stage increased all these traits in the two seasons. The data indicated that splitting nitrogen reduced $\mathrm{N}$ losses, increased nitrogen availability, particularly, at late growth stages, which improved grain filling rate and produced high grain yield. However, increase the harvest index by increasing the nitrogen doses was due to the increase the growth characters, plant height and the number of tillers per hill (Edwin et al., 2004). Such results are in line with those obtained by Peng et al., (1998), Kumar et al., (1999), Baiasubramanian (2002), and Mohamed (2006).

\section{Effect of time potassium applications:}

The Data showed that, apply the potassium fertilizer resulted in gradually increase in 1000-grain weight, grain yield ha ${ }^{-1}$ and harvest index in both seasons.

The highest values of mentioned traits were obtained with adding potassium fertilizer in two equal doses as half dose before transplanting + half dose at panicle initiation stage $(\mathrm{SI})$ compared with other treatments. The superiority of $(\mathrm{SI})$ might be due to partitioning the amount of Potassium through two doses during vegetative period, especially after late booting, which increased $\mathrm{K}$ availability, resulted in increasing carbohydrate translocation from source to sink, consequently, improve grain filling, grain yield and harvest index (Awan et al. 2007). Such results were reported by Meena et al. (2003), , Manzoor et al., (2008) and Mashmann et al. (2010).

\section{Effect of ascobien compound applications time:}

The results indicated that, foliar spraying of ascobien compound resulted in gradually increase in 1000-grain weight, grain yield/ha and harvest index in both seasons.

Rice plants sprayed with ascobien compound twice as a foliar application had recorded the highest values of 1000-grain weight, grain yield/ha and harvest index compared with the control and other treatments in 
both seasons. The ascorbic acid is synthesized in the higher plants and affects plant growth and development; it is product of D-glucose metabolism which affects some nutritional cycle's activity in higher plants and plays an important role in the electron transport system. Enhancement the growth rate in early growth stages will, reflected in higher grain yield attributes (number of panicle hill-1, panicle weight, number of filled grains panicle-1 and 1000-grain weight) then increase the grain yield (El-Kobisy et al. 2005).

Table 6: 1000-grain weight $(\mathrm{g})$, grain yield (t/ha) and harvest index (\%) of IR $69265 \mathrm{~A}$ as affected by Nitrogen, potassium and ascobin compound time applications and their interactions in 2012 and 2013 seasons

\begin{tabular}{|c|c|c|c|c|c|c|}
\hline \multirow{2}{*}{\begin{tabular}{|c|}
$\begin{array}{c}\text { Factor } \\
\text { (time of } \\
\text { application) }\end{array}$ \\
\end{tabular}} & \multicolumn{2}{|c|}{$\begin{array}{l}\text { 1000-grain weight } \\
(\mathrm{gm})\end{array}$} & \multicolumn{2}{|c|}{ grain yield (t/ha) } & \multicolumn{2}{|c|}{ Harvest index (\%) } \\
\hline & 2012 & 2013 & 2012 & 2013 & 2012 & 2013 \\
\hline \multicolumn{7}{|l|}{$\begin{array}{l}\text { Nitrogen (165 } \\
\mathrm{kg} \mathrm{N} / \mathrm{ha})(\mathrm{N}):\end{array}$} \\
\hline STI & $23.65 \mathrm{~b}$ & $23.55 \mathrm{~b}$ & $2.42 \mathrm{~b}$ & $2.57 \mathrm{~b}$ & $13.02 \mathrm{~b}$ & $14.13 \mathrm{~b}$ \\
\hline STIB & $24.00 \mathrm{a}$ & $24.14 \mathrm{a}$ & $2.78 \mathrm{a}$ & $2.90 \mathrm{a}$ & $14.58 \mathrm{a}$ & $15.27 \mathrm{a}$ \\
\hline ST & $23.22 \mathrm{c}$ & $23.10 \mathrm{c}$ & $1.90 \mathrm{~d}$ & $2.10 d$ & $11.28 \mathrm{c}$ & $12.22 \mathrm{c}$ \\
\hline ST 2:1 & $23.24 \mathrm{c}$ & $23.15 \mathrm{c}$ & $2.07 \mathrm{c}$ & $2.27 \mathrm{c}$ & $11.46 \mathrm{c}$ & $12.45 \mathrm{c}$ \\
\hline $\mathrm{F}-$ test & ** & ** & ** & ** & ** & ** \\
\hline \multicolumn{7}{|l|}{\begin{tabular}{|l|} 
Potassium \\
$\left(60 \mathrm{~kg} \mathrm{k}_{2} \mathrm{O} / \mathrm{ha}\right)$ \\
$(\mathrm{K}):$
\end{tabular}} \\
\hline Control & $23.08 \mathrm{c}$ & $22.65 \mathrm{c}$ & $1.93 \mathrm{c}$ & $1.99 \mathrm{c}$ & $10.63 \mathrm{c}$ & $11.76 \mathrm{c}$ \\
\hline$S$ & $23.64 \mathrm{~b}$ & $23.60 \mathrm{~b}$ & $2.26 \mathrm{~b}$ & $2.54 \mathrm{~b}$ & $13.14 \mathrm{~b}$ & $13.97 \mathrm{~b}$ \\
\hline SI & $23.87 \mathrm{a}$ & $24.20 \mathrm{a}$ & $2.68 \mathrm{a}$ & $2.85 \mathrm{a}$ & $13.99 \mathrm{a}$ & $14.82 \mathrm{a}$ \\
\hline $\mathrm{F}$ - test & $* *$ & ** & $\star *$ & $\star \star$ & $\star *$ & $\star *$ \\
\hline \multicolumn{7}{|l|}{$\begin{array}{l}\text { ascobien }(1 \\
\mathrm{gm} / \mathrm{I})(\mathrm{A}) \text { : }\end{array}$} \\
\hline Control & $23.13 c$ & $22.86 \mathrm{c}$ & $1.81 \mathrm{c}$ & $1.93 \mathrm{c}$ & $10.77 \mathrm{c}$ & $11.83 \mathrm{c}$ \\
\hline Once & $23.55 \mathrm{~b}$ & $23.45 \mathrm{~b}$ & $2.30 \mathrm{~b}$ & $2.51 \mathrm{~b}$ & $12.58 \mathrm{~b}$ & $13.51 \mathrm{~b}$ \\
\hline Twice & $23.90 a$ & $24.15 \mathrm{a}$ & $2.77 \mathrm{a}$ & $2.95 \mathrm{a}$ & $14.41 \mathrm{a}$ & $15.21 \mathrm{a}$ \\
\hline $\mathrm{F}$ - test & $* *$ & ** & $\star *$ & $\star *$ & ** & ** \\
\hline \multicolumn{7}{|l|}{ Interaction: } \\
\hline NXK & ** & ** & ** & ** & ** & ** \\
\hline NXA & * & ** & ** & ** & ** & ** \\
\hline KXA & ** & ** & ** & ** & ** & ** \\
\hline NXKXA & ** & ** & ** & ** & ** & ** \\
\hline
\end{tabular}

$\left({ }^{*}\right)$ Significant at $5 \%$ level, $\left(^{* \star}\right)$ highly Significant at $1 \%$ level, and (NS) Not Significant Letter(s) refer to Duncan's multiple range Test
S...... basal soil
T...... mid-tillering,
I........ panicle initiation, B........booting stage

A positive association between foliar application of ascobien and grain yield has been reported by Taha (2008) and Gharib et al., (2011).

\section{3-4. Effect of interaction:}

Data in Tables 6\&7 showed that the effect of interaction among all main treatments was highly significant in all characters in both seasons.

The interaction between nitrogen, potassium and ascobien compound application time had a significant effect on grain yield in the two seasons. 
Data presented in (Table 7) show that applying the nitrogen fertilizer in four equal doses (STIB) with potassium fertilizer in two equal doses (SI) under spraying twice with foliar ascobien compound produced the highest grain yield (resulted 3.69 and $3.96 \mathrm{t} / \mathrm{ha}$ ) in the two seasons.

The lowest grain yield (resulted 1.14 and $1.23 \mathrm{t} / \mathrm{ha}$ ) was obtained from the interaction of applying nitrogen fertilizer in two equal doses (ST) without apply potassium fertilizer (control) under without spraying foliar ascobien compound (control) in both seasons. The results were agreement with Nagarathna and Prakasha (2007), Pandey et al. (2007) and Gharib et al. (2011).

Table 7: Grain yield ( $\mathrm{t} / \mathrm{ha}$ ) as affected by the interaction among nitrogen, potassium and ascobien compound treatments in 2012 and 2013 seasons

\begin{tabular}{|c|c|c|c|c|c|c|c|}
\hline \multirow{3}{*}{$\begin{array}{c}\text { Nitrogen } \\
(165 \mathrm{~kg} \\
\mathrm{N} / \mathrm{ha})(\mathrm{N}):\end{array}$} & \multirow{3}{*}{$\begin{array}{c}\text { Potassium } \\
(60 \mathrm{~kg} \\
\left.\mathrm{k}_{2} \mathrm{O} / \mathrm{ha}\right)(\mathrm{K}):\end{array}$} & \multicolumn{6}{|c|}{ ascobien $(1 \mathrm{gm} / \mathrm{l})(\mathrm{A})$ : } \\
\hline & & \multicolumn{3}{|c|}{2012} & \multicolumn{3}{|c|}{2013} \\
\hline & & Control & Once & Twice & Control & Once & Twice \\
\hline \multirow{3}{*}{ STI } & Control & $1.78 n$ & $2.11 \mathrm{k}$ & $2.43 \mathrm{i}$ & $1.73 \mathrm{q}$ & $2.15 \mathrm{mn}$ & $2.37 \mathrm{k}$ \\
\hline & B & 2.031 & $2.51 \mathrm{hi}$ & $3.00 \mathrm{e}$ & $2.21 \mathrm{lmn}$ & $2.97 \mathrm{f}$ & $3.31 \mathrm{~d}$ \\
\hline & $\mathrm{SI}$ & $2.18 \mathrm{j}$ & $2.60 \mathrm{~h}$ & $3.14 \mathrm{~d}$ & $2.23 \mathrm{~lm}$ & 2.80gh & $3.35 \mathrm{~d}$ \\
\hline \multirow{3}{*}{ STIB } & Control & $1.44 p$ & $2.05 \mathrm{kl}$ & $2.73 \mathrm{~g}$ & $1.48 \mathrm{~s}$ & $2.11 \mathrm{~m}$ & $2.69 \mathrm{hi}$ \\
\hline & $\mathrm{S}$ & $2.52 \mathrm{hi}$ & $2.92 \mathrm{f}$ & $3.37 \mathrm{~b}$ & $2.71 \mathrm{hi}$ & $3.12 \mathrm{e}$ & $3.46 \mathrm{c}$ \\
\hline & $\mathrm{SI}$ & $3.03 \mathrm{e}$ & $3.27 \mathrm{c}$ & $3.69 \mathrm{a}$ & $2.96 \mathrm{f}$ & $3.64 \mathrm{~b}$ & $3.96 \mathrm{a}$ \\
\hline \multirow{3}{*}{ ST } & Control & $1.14 \mathrm{q}$ & 1.560 & $1.93 \mathrm{~m}$ & $1.23 \mathrm{t}$ & $1.64 \mathrm{gr}$ & 1.940 \\
\hline & $\mathrm{S}$ & $1.38 p$ & $1.76 n$ & $2.21 \mathrm{j}$ & $1.68 \mathrm{gr}$ & $2.07 n$ & $2.63 \mathrm{ij}$ \\
\hline & SI & $1.76 n$ & $2.47 \mathrm{i}$ & $2.91 \mathrm{f}$ & $2.14 \mathrm{mn}$ & $2.54 \mathrm{j}$ & $3.08 \mathrm{ef}$ \\
\hline \multirow{3}{*}{ ST 2:1 } & Control & 1.510 & 2.011 & $2.52 \mathrm{hi}$ & $1.56 \mathrm{rs}$ & $2.30 \mathrm{kl}$ & $2.69 \mathrm{hi}$ \\
\hline & $\mathrm{S}$ & $1.16 q$ & $1.78 \mathrm{n}$ & $2.45 \mathrm{i}$ & $1.46 \mathrm{~s}$ & $2.09 \mathrm{mn}$ & $2.85 \mathrm{~g}$ \\
\hline & $\mathrm{SI}$ & $1.78 \mathrm{n}$ & $2.52 \mathrm{hi}$ & $2.88 \mathrm{f}$ & $1.84 \mathrm{p}$ & $2.66 \mathrm{ij}$ & $3.03 \mathrm{ef}$ \\
\hline
\end{tabular}

Means followed by the same letter are not significant at the $5 \%$ level according to Duncan's multiple range test.

$$
\begin{aligned}
& \text { S...... basal soil } \\
& \text { I....... panicle initiation }
\end{aligned}
$$

T...... mid-tillering

B........booting stage

\section{CONCLUSION}

Under the condition of this study it can be concluded that nitrogen fertilizer applicaion in four equal doses as basal soil, mid- tillering, panicle initiation and booting stage (STIB) with potassium fertilizer addition in two equal doses (SI) under twice foliar application with ascobien compound could be recommended for optimum grain yield and productivity for 2034 hybrid rice seed. 


\section{REFERENCES}

Abd EL-Hameed, A.M., S.H. Sarhan and H.Z. abd EL-Salam (2004). Evaluation of some organic acids as foliar application on growth, yiled and some nutrient contents of wheat. J. Agric. Sci., Mansoura Univ., 29 (5):2475-2481.

Awan, T.; Z. Manzoor; E. Safdar and M. Ahmed (2007). Yield response of rice to dynamic use of potassium in traditional rice growing area of Punjab. Pak. J. Agric. Sci., 44(1): 130-134.

Baiasubramaniayan R. (2002). Response of hybrid rice (Oryza sativa L.) to level and time of application of nitrogen. Indian J. of Agron. 47(2): 203-206.

Black, C.A., D.D. Evans, L.E. Ensminger and F.E. Clark (1965). Methods of Soil Analysis. Part 2- Chemical and microbiological properties. American Soc. of Agronomy, Inc., Publisher, Madison, Wisconsin, USA.

Dheebakaran G. and S. Ramasaamy. (2000). Source and times of split of nitrogen on $\mathrm{N}$ uptake and its efficiency on irrigated rice. Madras Agric. J. 86(7-9): 429- 431.

Duncan, B. D. (1955) . Multiple range and multiple F. test . Biometrices, 11 : $1-42$.

Ebaid, R.A. and S.A. Ghanem (2001). Effect of nitrogenous and potash fertilizers on the productivity of Sakha101 rice cultivar. J. agric. Sci. Mansoura Univ., 26(4); 1833-1840.

Edwin L., J. Krisjanarajan and S. Premsekhar. (2004). Irrigation and nitrogen application schedules for hybrid ADTRH1 rice (Oryza sativa L.) in tamil nadu. Indian. J. of Agron. 49 (1):37-39.

El-Kobisy,D.S. ; K.A. Kady ; R.A. Medani and R.A. Agamy(2005). Response of pea plant (Pisum sativum L.) to treatment with ascorbic acid. Egypt J. Appl. Sci., 20:36-59.

El-Shazly,W.M.O and M.F. EL-Masri (2003). Response of Giza 89 cotton cultivar to foliar application of ascorbic acid, gibberelic acid, phosphorus and potassium. J. Agric. Sci., Mansoura Univ., 28 (3): 1579-1597.

Foyer,C.H. (1993).Ascorbic acid. In. R.G. Alscher and J.I. Hess (eds.) Antioxidants in higher plants. pp. 31-58. CRC press, Inc. Florida.

Foyer, C.H. and Harbineson (1994). Oxygen metabolism and the regulation of photosynthetic electron transport. In: C. H. Foyer and P. M. Mulhneaux (Eds). Causes of photooxidative stress and amelioration of defense systems in plants. Boca Raton, FL:CRC Press p.1-42.

Gharib, H.S. T.F. Metwally ,S.S. Naeem, E.E. Gewaily, (2011). Influence of Some Stimulating Compounds and Nitrogen Fertilizer Levels On Growth And Yield Of Hybrid Rice Egypt. Zagazig J.Agric. Rec., 38 No.(1):1-21, Vol. 
Ghaurab,. M.H.H and G.A. Wahdan (2000). Response of cotton plants to foliar application of acobine and Ascorbic acid. Egyptian . journal of Agricultural. Research- 78 (3); 1195-120.

Gomez, K.A. and A.A. Gomez (1984). Statistical Procedures for Agricultural Research, $2^{\text {nd }} E d$. John Wiley and Sons, Inc. New York.

Gorgy R.N. I.M. EL-Rewainy, A.A. Abou Khalifa and I.S. El-Refaee. (2006). effect of some cultural practices on the productivity of Sakha104 rice cultivar planted with broadcast methods. J.Agric. Res.32(1):31-47, Tanta Univ., Egypt.

IRRI, (International Rice Research Institute) (1998). Program report for 1997: Los Banos (Phillippines). International Rice Research Institute, 175 $P$.

Krishnakumar, S.; R. Nagarajan; S.K. Natarajan; S Jawahar and J.B. Pandian (2005). NPK fertilizers for hybrid rice (oryza sativa) productivity in Alfisols of sothern Districts of Tamil Nadu. Asian J. of plant Sci., 4(6):574-576.

Kumar, R.M., K. Padmaj and S. V. Subbaiah (1999). Tools for plant-based nitrogen management in different rice varieties grown in south India, IRRN, 24 (3): 23-24.

Manjappa K., N. Kataraki, S. Kelaginamani and V. Jowkin (2008). Potash management in rainfed transplanted paddy in lowland rice soils. Karnataka J. Agric. Sci. 21(4): 482-484.

Manzoor, Z.; T. Awan; M. Ahmed; M. Akhter and F. Faiz (2008). Effect of split application of potash on yield and yield related traits of basmati rice. J. Anim. PI. Sci., 18(4): 120-124.

Mashmann, E.; N. Slaton; R. Corwright and J. Norman (2010). Rate and timing of potassium fertilization and fungicide influence rice yield and stem rot. Agron. J., 102(2): 163-170.

Meena, M.; S. Surendra and Y.S. Shivay (2003). Response of hybrid rice to nitrogen and potassium application in sandy clay loam soils. Indian J. of Agric. Sci., 73(1): 8-11.

Mikhael, B.B.Y. (2007). Studies on some rice cultivars productivity. M.Sc.Thesis, Fac. Agric., Kafr El-Sheikh Univ., Egypt.

Mikhael, B.B.Y. (2010). Fertilizer requirements for hybrid rice. Ph.D. Thesis, Fac. Agric., Kafr El-Sheikh Univ., Egypt.

Mohammed, M. M. A (2006). Effect of some agricultural treatments on yield of hybrid rice M. Sc. Thesis, Fac. Of Agric. Al-Azhar Univ., Egypt. Pp. 96.

Nagarathna, T. and H. Prakasha (2007). Synchronization of potassium supply in rice hybrids. Environment and Ecology, 25(3-4): 967-968.

Noctor, G. and C.H. Foyer (1998). Ascorbate and glutathione: Keeping active oxygen under control. Annu. Rev. of plant physiol. and Plant Mol. Biol., 49:249-279.

Pandey, N.; K. Verma; A. Anurag and S. Tripathi (2007). Integrated nutrient management in transplanted hybrid rice (Oryza sativa, L.). Indian J. of Argon., 52(1): 49-51. 
Pengs.;J. Yang, F. V. Carcia R.C. Laza, R.M. Visperas, Al. Sanico, A.Q. Chover and S.S. Virmani (1998). Physiology-based crop management for yield maximization of hybrid rice. In: Virmani S.S.,Siddiq. E.A., Muralidharan K., editors. Advances in hybrid rice technology. Proceeding of the third Interanational symposium on hybrid rice, 14-16 November 1996, Hyderabed, India. Loss Banos, (Philippines) IRRIP 157-176.

Pignocchi, C. and C.H. Foyer (2003). Apoplastic ascorbate metabolism and its role in the regulation of cell signaling. Curr Opin in plant Biol. 6:379-389.

RRTC- Rice Research and Training Center (2012). Proceeding of the $10^{\text {th }}$ National program work shop ( final results of 2008), $179 \mathrm{p}$.

Smirnoff, N. (2005). Ascrobate, tocopherol and carotenoids: mestabolism, pathway engineering and function. In: N. Smirnoff, ed. Antioxidants and Reactive Oxygen Spexies in plants, pp. 53-86. Blackwell publishing Ltd, Oxford, UK.

Stalin, P.; T.M. Thiyagarajan and R. Rangarajan (1999). Nitrogen application strategy use efficiency in rice. Oryza 36 (4): 322-326.

Surekha, K; M. Narayana Reddy and R. T. M. Kumar (1999). Yields attributes and yield of rice (Oryza sativa) hybrids as influenced by nitrogen sources and its splits application. India J. of Agron., 44 (1) : 90-88.

Taha, Hanan A.E.N. (2008). Response of rice plant to some different fertilizer compounds. M.Sc. Thesis,Agron. Dept., Fac. Of Agri., Kafelsheikh Univ.

Tahir, H.A.; Z. Manzoor; M. Ehsan and A. Mushtaq (2007). Yield response of rice to dynamic use of potassium in traditional rice growing area of Pung JaB. Pak. J. Agric., 44 (1).

Virmani, S. S. (1996). Hybrid rice. Advances in Agronomy, 57: 377-462 Voss, M. A. and E. Zini (1993). Forms and dates of urea to irrigated rice 1992/1993. Anais 20-24 stembro 1993. Pelotas, Brazilio Centro. De. Pesquisa Agropecuaris de Olima. Temperado. EMBRAPA (1993) 163-164 (PT).

Zaman, F.U., A.O. Bastawisi, A.E. Draz, H.F. El-Mowafy and M.I. AboYoussef. (2002) .Hybrid rice technology in Egypt. Present status and future strategies.

Zaratin, C.; S.A. Souza; A.C. Pantano; M.E. Sa and S. Buzetti (2004). Effects of four potassium doses on six sprinkler irrigated rice upland cultivars .I. yield and yield components. Cientifica Jaboticabal, 32 (2); 115120. 
تأثير مواعيد اضافة السماد النتروجينى والبوتاسي والرش بمركب الاسكوبين على الألى إنتاج تقاوي الأرز الهجين

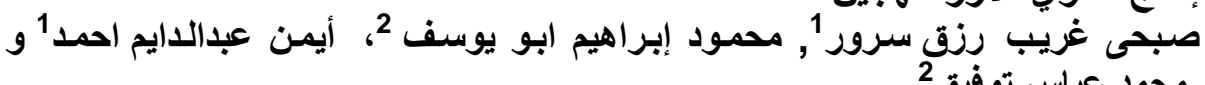
محمد عباس توفيق

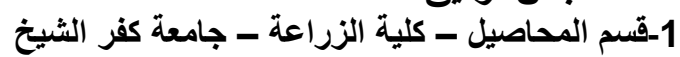

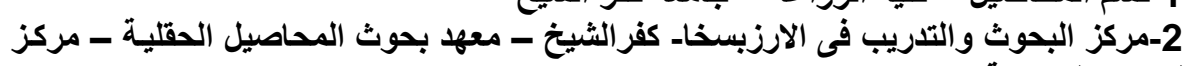

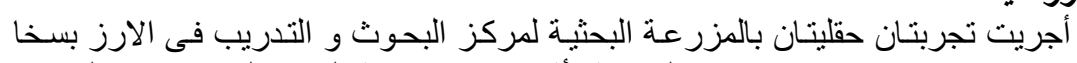
البحوث الزراعية البحوث

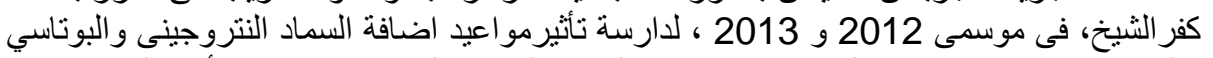

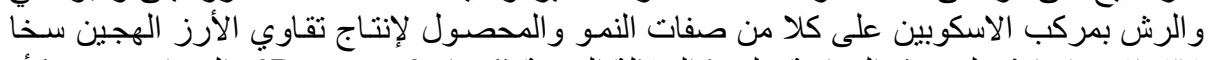

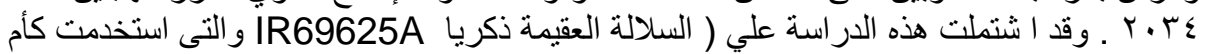

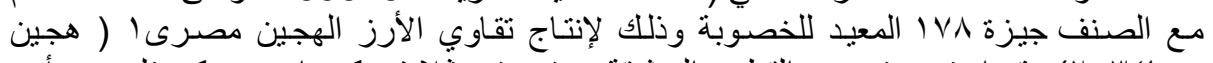

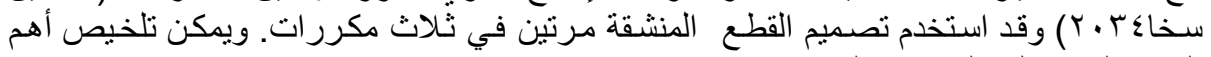

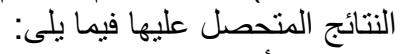

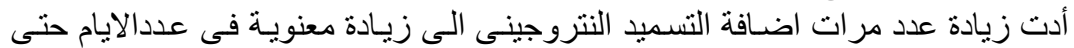

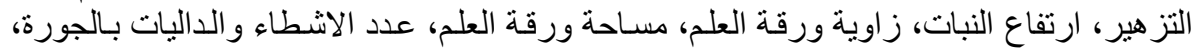

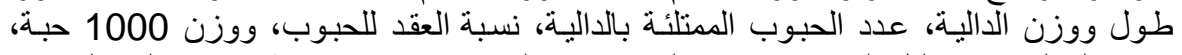

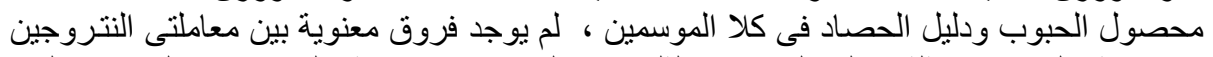

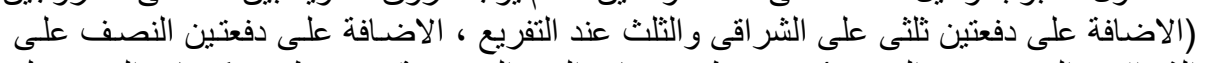

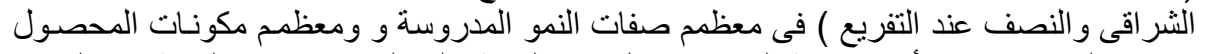

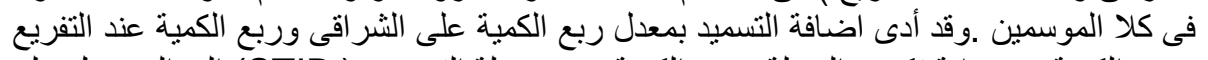

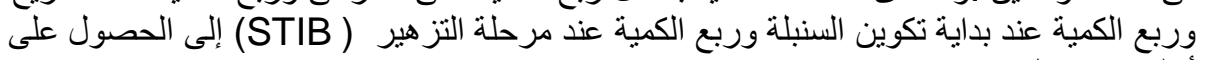

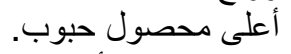

كما أدت اضافة التسميد البوتاسى الى زيادة معنوية فى عدد الداليات بالجورة، معدل انبثاق

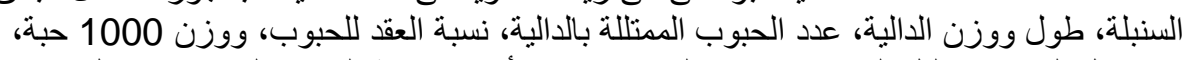

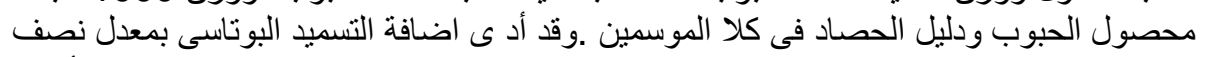

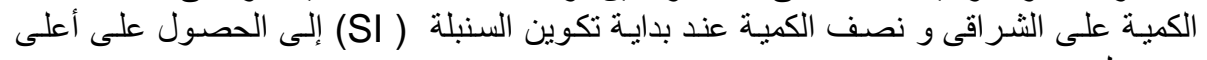

كما سجل الرش الورقى بمركب الاسكوبين على مرتين بعد 25 و 45 يوم من الإبـ الثتل محصول حبوب.

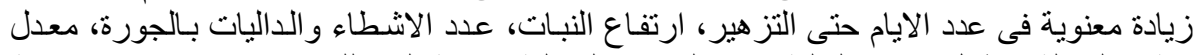

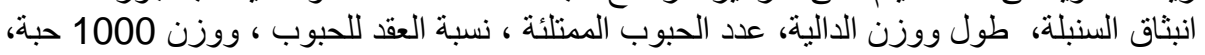

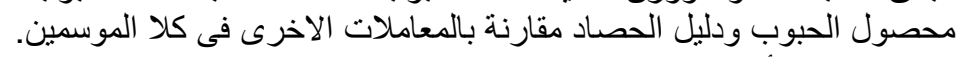

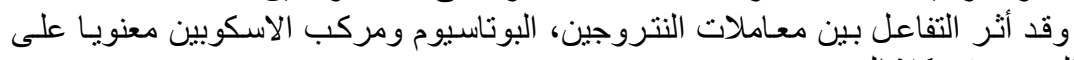

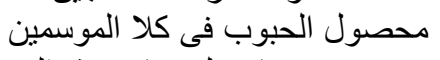

وبناء على نتائج هذه الد راسة يمكن التوصية باضافة السماد النتروجينى بمعدل ربع الكمبية

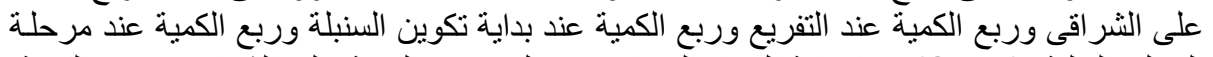

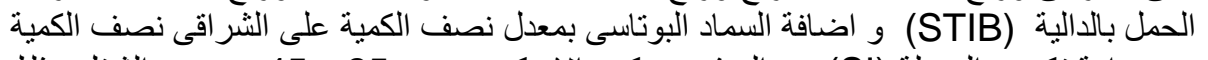

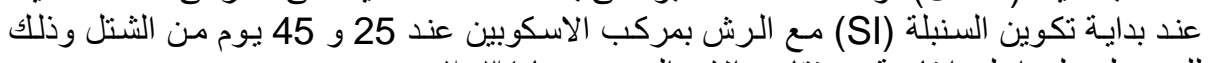

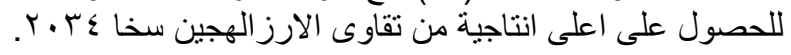

